NiKoletT RÉKASI - CARMEN SVASTICS -

CSILLA CSERTI-SZAUER - GÁBOR KovÁCS -

VERONIKA KALÁSZ

\title{
Career Paths: Work Opportunities for Persons with Visual Impairment
}

\section{INTRODUCTION AND THEORETICAL BACKGROUND}

People with disabilities are one of the marginalised social groups whose fundamental human rights, such as the right to work, need to be emphasised and strengthened. The Convention on the Rights of Persons with Disabilities (CRPD) targets the issue employment and occupation in Article 27, where it states that people with disabilities have the right to work and also prohibits discrimination in the workplace. Employment, however, cannot be interpreted without the concept of accessibility (CRPD, Article 9). It is impossible to take a job without full accessibility, i.e. the physical and infocommunication accessibility of the environment. For people with visual impairment, it is not enough for instance to have tactile guidelines in the workplace itself, but a well-developed and comprehensive transport system is needed as a whole. Or it is not enough to provide a computer, the device must also be equipped with screen readers and/or screen magnifiers to enable work. According to the social model of disability, it is not the impairment that disables a person in the first place but the barriers of the environment. Viewing disability as a social construct makes the physical limitations of a person less of a problem, it is the exclusionary mechanisms in society that actually pose the obstacles (Könczei \& Hernádi, 2011; Shakespeare 2006, 2013). In the context of the labor market, it is not the disabled worker who needs to be adapted to the working conditions, but it is the job that needs to be carved for the employee.

Although the social model gives an understanding of disability, the phenomenon is rather complex, so the question always arises: how can we grasp its essence as fully as possible? Goodley's (2016) answer to the question is to consider disability as the center of a matrix where besides being a social construct, disability is also a medical issue to cure (medical model), a social minority besides women, ethnicities or elderly people (minority model), a common cultural experience (cultural model) (Flamich \& Hoffmann, 2015) or a form of social oppression undermining physical and psycho-emotional well-being (social relational model). As the phenomenon of 
disability is by no means static, but dynamic and constantly changing, it cannot be forced into linear frames (Hernádi, 2015).

Disability Studies (DS) calls attention to the manifold aspects of blindness, as according to Paulson, blindness means "very different things, and moreover it is very different things, at different times, different places, and in different kinds of writing" $(1987,4)$. There is truly an abundance of definitions of blindness or visual impairment, it mostly depends on the actual context: at the doctors', at school, in social service or at the rehabilitation centre. Although the definitions may not even have much in common, still, they are all based on a socially expected able-bodied normality. They rather demonstrate an expected functioning, how people should be able to see, than the true visual abilities of the person or what kind of support they need (Titchkosky, 2002). This idea comes up in Michalko's (2010) theory of Cool Blindness Time, where he describes two different "time zones": one for sighted people and one for blind people. They exist next to each other and rarely meet. When they do, it is almost always about the issue of how blindness could be cured or fixed and thus integrated into the world of sighted people.

\section{ABOUt THE EMPLOYMENT OF PERSONS WITH DISABILITIES}

In today's society, paid work is generally considered highly important. It does not only provide a living but has crucial effects on the skills, mental health, social life and general well-being of the individual. It gives a framework to one's life, defines adulthood, citizenship and social standing and provides the opportunity to develop a valued and positive identity as a useful and appreciated member of the work force in society (Rose, 2015). Unemployment at the same time not only causes poverty but also correlates with physical and mental ill-health, along with other socially, emotionally, psychologically adverse effects and a generally low quality of life (Bánfalvy, 2003). No wonder, employment is a crucial aspect in the social participation of persons with disabilities and several employment policies and programmes target inclusion in the labour market (Bánfalvy, 2020).

At the same time, according to the Analysis of the World Health Survey, the general employment rate for men with disability is $52.8 \%$ while for women with disability $19.6 \%$, compared with $64.9 \%$ for non-disabled men, and $29.9 \%$ for nondisabled women (World Report on Disability 2011). In Hungary around $23 \%$ of the working age population with disabilities is working (Krekó \& Scharle, 2020), which is considered rather low in the European Union as the average EU rate of employment for persons with disabilities is $50 \%$ (Lecerf, 2020). In general the disability employment gap between disabled and non-disabled persons has narrowed in recent years, especially for those with a tertiary education; the gender gap has, however, widened with female workers with disabilities working fewer hours (Eurofound 2018).

Labour market outcomes are influenced in general by a number of factors: among others education and productivity differentials; labour market imperfections related to employers' attitudes, discrimination and prejudice; or disincentives created by disability benefit systems. Persons with disabilities are also frequently considered lacking the potential to become members of the workforce. Perception, 
apprehensiveness, myth and prejudice continue to limit understanding and acceptance of disability, such as fears about the expenses of reasonable adjustment, job carving or digital accessibility (UN Disability and Employment). Nevertheless, many employers have found that persons with disabilities are more than capable in fulfilling the tasks and challenges at a workplace.

\section{ABOUT THE EMPLOYMENT OF PERSONS WITH VISUAL IMPAIRMENTS}

According to the WHO statistics, there are about 1 billion people globally with moderate or severe visual impairment and blindness. The most common causes are cataract, uncorrected refractive errors, age-related macular degeneration, glaucoma and diabetic retinopathy. In Hungary, according to the Population Census conducted by the Hungarian Central Statistical Office in 2011, there are 490,578 persons with disabilities. (Data is based on self-declaration.) Among them there are 9,054 people who are blind and 73,430 people have low vision (i.e. functioning vision to a degree but below the so-called good vision) including children below 14 and seniors above 60 . This population is rather small compared to the group of persons with disabilities but the prevalence of visual impairment between the ages of 0-14 within the entire population increases in every ten years (Kiss \& Pajor, 2021).

The employment rate of persons with vision impairment may vary greatly globally (24\% in Australia, $28 \%$ in Canada, 32\% in New Zealand and $44 \%$ in the U.S.; McDonnall \& Sui, 2019). In Hungary, the employment rates of the economically active population of persons with visual impairment (aged 15-60+) are rather low: only $11.7 \%$ of blind persons and $13.7 \%$ of persons with low vision are employed while inactivity is over $86 \%$ and $82 \%$ respectively (Hungarian Central Statistical Office 2011). (The percentage of economically active but unemployed persons is also low.) Comparing employment rates of persons with vision impairment over time and place is rather challenging due to changing definitions of vision impairment, types of employment or research-related issues like small samples or methodological discrepancies (Lund \& Cmar 2019).

Closely related to labour market success is the possibility to benefit from an appropriate career guidance process and employment service (Kenderfi, 2019; Borbély-Pecze \& McCarthy, 2020; Török, 2020). While educational attainment of persons with vision impairment is relatively in line with the non-disabled population in Hungary ( $20 \%$ of persons with low vision and around $18 \%$ of blind persons have a secondary school certificate while $8.8 \%$ and $8.3 \%$ has a university degree, respectively; Hungarian Central Statistical Office 2011), the transition to the primary labour market is rather difficult and poses several obstacles. While there is general agreement in the literature that best practices in transition processes include vocational assessments, training in vocational and social skills, career education curricula, paid work experience, traineeship programs as well as collaboration among agencies and the involvement of families (Nagle, 2001), these are still unfortunately mostly lacking in their implementation. 


\section{THE IMPORTANCE OF CAREER GUIDANCE IN THE LIVES OF PERSONS WITH VISUAL IMPAIRMENT}

More than a decade ago, the OECD and the European Commission (2004) published their report entitled Career Guidance: a Handbook for Policy Makers which highlighted the importance of guidance services in supporting lifelong learning and labour market integration. An analysis comparing the career guidance systems in thirty-six countries shows that making the right quality and quantity of services available as early as primary and secondary education can lay the foundations for a successful future career and positive labour market choices for young people. This is especially true for children and young people with special educational needs and adults with disabilities.

A career path can be seen as gaining a higher position within the work organization, but in addition to vertical advancement, expanding, deepening and personal development of professional knowledge or filling a new, interesting job can also be considered a career (Warr, 2011). The OECD and the World Bank define career guidance and orientation as a set of services that support individuals at any age and at any stage of their lives in making education, training and labour market decisions. Services include the provision of career information, career counselling, and career education including the strengthening of competences that support career management (Watts, 2013). Supporting persons with disabilities to build their careers is a priority for a number of reasons: their integration into the labour market is hindered and their career success is generally lower than that of their non-disabled peers (Kulkarni \& Gopakumar, 2014).

\section{TRENDS IN THE PRACTICE OF SUPPORTING CAREER GUIDANCE AND DEVELOPMENT}

The processes that affect the careers of persons with disabilities and the social, cultural values and work environment that determine a place in life and in the labour market are rather complex and are rapidly changing over time. Thus, if we look at the situation of a person with disability from the aspect of employment and career opportunities, we find ourselves in a multidimensional, changing system of relationships (Sears et al., 2014). In addition to individual cognitive abilities, the planning of individual development and a career required must consider both social and economic circumstances, as well as socio-cultural endowments and the attitudes of the immediate environment (Brown, 2002).

Szymanski analyses the various theoretical approaches and processes influencing the working careers of persons with disabilities by integrating them into an ecological model. The model shows the embeddedness of the individual in specific contexts, e.g. family, socioeconomic status, education, and characteristics of the immediate work environment, such as organizational culture, work requirements, 
physical and built environment, etc. Thus, individual career counselling must cater for all these to achieve the best possible outcomes in realising employment (Szymanski \& Vancollins, 2003). In the procedures of implementation, complex and personalized individual counselling and process tracking is needed, according to the individual's situation. Within the framework of personal counselling for persons with visual impairment, the vocational rehabilitation counsellor, mentor, vocational counsellor can play a significant role in increasing career opportunities, from career orientation to job selection, job retention as well as long-term career planning and accompanying (Dávid et al., 2008; Sears et al., 2014; Cruden \& Steverson, 2021). Domestic and international practice and the relevant literature from recent decades agree that the basic condition for successful long-term and adequate employment is individual case management, during which career counselling is provided within the framework of personalized, high-quality, complex labour market services. a successful career can thus be the result of e.g. the modernization of outdated skills and the associated welldesigned process of individual development (Gere, 2009).

\section{OUR RESEARCH PROJECT}

The overall picture of the employment of persons with visual impairment in Hungary is rather mixed with average rates of education but lower rates of employment than the general population. This discrepancy raises the question: why do they have difficulties and what could be done about it? In our research project we would like to find some answers to that using the narrative life-story interview as a research method. The interviews with persons with visual impairment will serve to detect the milestones and important stations regarding their career paths (Rosenthal, 1993). This choice of research method fits to the critical aspects of Disability Studies as it puts the individual in the center and highlights the importance of not being normalitybased. It also allows us to find our place on the matrix of disability models without explicitly fixing disability to one single concept. It is also not unknown in the field of DS to use the method of interview to examine the connection between work and visual impairment as French (2017) conducted a research in the UK with 50 people with visual impairment where she used in-depth interviews focused on their work experiences. Narrative life-story interviews give us a more detailed and complex path of life and hopefully we will be able to detect more details between the individual experiences and the struggles in employment.

\section{Discussion AND CONCLUSIONS}

In the present paper we wished to present the importance of career guidance regarding the labour market position of persons with visual impairment from a DS perspective. There are carrier guidance and labour market services in Hungary, but these are not always available to many persons with disabilities for a variety of reasons: the services are concentrated in the capital and bigger towns, the interconnection of different actors is not always systematic, and service users tend to have insufficient information about the services provided. 
The so-called Elementary Rehabilitation Service Centres set up on a county basis employ social workers who, amongst many other tasks, provide career guidance and labour market counselling for persons with visual impairment. However, this often lacks authentic labour market statistics and a strategic approach and often focuses on the employment in sheltered workshops specifically created for people with disabilities. The Hungarian Institute for the Blind for instance offers candle and pottery workshops or broom and brush-making workshops as historically "classical" activities for people with visual impairment. Becoming a therapeutic masseur is also a rather typical job for persons with visual impairment, which can nevertheless be exercised as an employee in mainstream employment e.g. in baths. The possibility of becoming an entrepreneur and avoiding ableist organisational, workplace expectations is unfortunately little, as developing entrepreneurial skills and competences (e.g. drafting a business plan, managing finances, negotiation technique, contracting, etc.) - besides securing a start-up capital - is not part of vocational education and vocational rehabilitation services (Svastics et al., 2020).

Persons with visual impairment can also decide to continue their studies and pursue a university degree. Although the Hungarian Law on National Higher Education clearly declares the educational right of persons with disabilities to earn a degree and even supports accessibility in universities, real choices remain rather limited. According to Kovács (2011), the most inclusive university programmes are Humanities (e.g. foreign languages, History), Law, as well as some of the Social Sciences (e.g. social worker) and Computer Sciences. Based on governmental prescriptions, universities tend to have a support network for students with special needs, still students often struggle with technical-organisational, legal and personal issues (Fazekas, 2019). Information-flow, attitudes and personal obstacles as barriers are reflected in the fact that while Eötvös Loránd University of Budapest organised a course called Special career management for students with disabilities in 2016, only 11 students - four of them students with visual impairment - out of the 306 registered students with disabilities participated.

In the present paper we have introduced the first steps of an explorative research study on narrative life-stories of persons with visual impairment to gain an insight and understanding of career guidance and labour market services in their career paths. Our aim in the current paper was to provide an overview of existing research results and inspire the launch of further research and development projects regarding career guidance and career development for persons with disabilities. We believe that there is a strong need in reaching the successful labour market inclusion of persons with disabilities through new, comprehensive and human-rights based domestic research initiatives and services.

\section{ACKNOWLEDGEMENTS}

We are grateful for the support of our supervisors, György Könczei and Csaba Bánfalvy for their advice as well as for the financial support of the 'Doctoral consortium call' of the Doctoral School of Education of the Faculty of Education and Psychology at Eötvös Loránd University. Without this support our study would not have been completed. 


\section{References}

Bánfalvy Cs. (2003). a munkanélküliség szociálpszichológiájáról. Budapest: Akadémia Kiadó.

Bánfalvy Cs. (2020). The Social Integration of Disabled Persons - The Contribution of Education and Employment. Hungarian Journal of Disability Studies \& Special Education, 2020(2), 10-28. https://doi.org/10.31287/FT.en.2020.2.3

Borbély-Pecze, T. B., \& McCarthy, J. (2020). Aims for, and access to, career development. Opus et Educatio: Munka és nevelés, 7(2), 112-123. http://dx.doi.org/10.3311/ope.373

Brown, D. (2002). Career choice and development (4th ed.). Jossey-Bass.

Dávid A., Gadó M., \& Csákvári J. (2008). Látássérült emberek elemi és foglalkozási rehabilitációja - Útmutató látássérült emberek rehabilitációjával foglalkozó szakemberek számára. Fogyatékos Személyek Esélyegyenlőségéért Közalapítvány. https://fszk.hu/wpcontent/uploads/2016/05/latasserult_emberek_elemi_es_fog_rehab.pdf [Accessed: 07. 09. 2021.]

Davis, E. (2019). Structures of seeing: blindness, race, and gender in visual culture. The Senses and Society, 14(1), 63-80. https://doi.org/10.1080/17458927.2019.1569331

ELTE Szolgáltatóközpont (2016). Speciális karriermenedzsment kurzust tartott a Szolgáltató Központ. https://karrierkozpont.elte.hu/specialis-karriermenedzsment-kurzust-tartotta-szolgaltato-kozpont/ [Accessed: 07. 09. 2021.]

Eurofound (2018). The social and employment situation of people with disabilities. Luxembourg: Publication Office of the European Union. https://www.eurofound.europa.eu/sites/ default/files/ef_publication/field_ef_document/ef18023en.pdf [Accessed: 31. 08. 2021.]

Fazekas, Á. S. (2019). The Journey towards Universal Design in the Teaching and Learning Environment in Hungarian Higher Education. The Ahead Journal, 9. https://www.ahead. ie/journal/The-journey-towards-Universal-Design-in-the-Teaching-and-LearningEnvironment-in-Hungarian-Higher-Education- [Accessed: 07. 09. 2021.]

Flamich, M. \& Hoffmann, R. (2015). Meddig kísért a múlt? a kulturális fogyatékosságtudomány szerepe, perspektívái a diverzitás megismerésében, elfogadásában és tiszteletében. In Hernádi I. \& Könczei Gy. (eds). A felelet kérdései között. Fogyatékosságtudomány Magyarországon (pp. 48-68). Budapest: Eötvös Loránd Tudományegyetem, Bárczi Gusztáv Gyógypedagógiai Kar. http://www.eltereader.hu/media/2015/07/A_felelet_ kerdesei_kozott_READER1.pdf [Accessed: 07. 09. 2021.]

French, S. (2017). Visual Impairment and Work. Experiences of Visually Impaired People. London: Routledge Taylor and Frances Group. https://doi.org/10.4324/9781315569536

Gere I. (2009). a foglalkozási rehabilitáció Magyarországon: a szabályozás múltja, jelene, jövője. Fogyatékosságtudományi Tanulmányok XI. Budapest: Eötvös Loránd Tudományegyetem, Bárczi Gusztáv Gyógypedagógiai Kar. https://mek.oszk. hu/09500/09537/09537.pdf [Accessed: 07. 09. 2021.]

Goodley, D. (2016). Disability Studies. An Interdisciplinary Introduction (2nd ed.). SAGE Publications.

Hernádi I. (2015). Problémás testek. Nőiség, szexualitás és anyaság testi fogyatékossággal élő magyar nők önreprezentációiban. Doktori értekezés. Pécs: Pécsi Tudományegyetem Bölcsészettudományi Kar. http://pea.lib.pte.hu/bitstream/handle/pea/14749/hernadiilona-phd-2015.pdf [Accessed: 19. 03. 2018.]

Hungarian Central Statistical Office (2011). https://www.ksh.hu/nepszamlalas/tablak fogyatekossaggal_elok_helyzete [Accessed: 07. 09. 2021.]

Hungarian Law on the National Higher Education. https://net.jogtar.hu/jogszabaly?docid= a1100204.tv [Accessed: 07. 09. 2021.]

Kenderfi M. (2019). A pályaorientáció elmélete és gyakorlata hazánkban. Munkaügyi Szemle, 62(4), 52-61. http://munkaugyiszemle.hu/palyaorientacio-elmelete-es-gyakorlata-hazankban [Accessed: 07. 09. 2021.].

Kiss E. \& Pajor E. (2021). Population Features of Visually Impaired Children and Their Parents Living in Hungary. European Journal Of Mental Health, 16(1), 38-52. https://doi. org/10.5708/EJMH.16.2021.1.3

Könczei Gy. \& Hernádi I. (2011). A fogyatékosságtudomány fő fogalma és annak változásai. In Nagy, Z. É. (ed.) Az akadályozott és az egészségkárosodott emberek élethelyzete Magyarországon (pp. 7-21). Budapest: NCSSZI.

Kovács, K. (2011). A fogyatékossággal élő hallgatók helyzete a hazai és néhány külföldi ország felsőoktatási intézményeiben. Pedagógusképzés, 9(38). https://doi.org/10.37205/TELhun.2011.3-4.05 
Krekó J. \& Scharle Á. (2020). Megváltozott munkaképesség, rokkantság, rehabilitáció. In Fazekas, K., Elek, P. \& Hajdu, T. (eds). MUNKAERÖPIACI TÜKÖR 2019. Közgazdaságés Regionális Tudományi Kutatóközpont. https://kti.krtk.hu/publikacio/publikaciokategoria/munkaeropiaci-tukor/[Accessed: 09. 08. 2021.]

Kulkarni, M. \& Gopakumar, K. V. (2014). Career Management Strategies of People With Disabilities. Human Resource Management, 53(3), 445-466. https://doi.org/10.1002/ hrm. 21570

Lecerf, M. (2020). Employment and disability in the European Union. European Union. https://www. europarl.europa.eu/RegData/etudes/BRIE/2020/651932/EPRS_BRI(2020)651932_ EN.pdf [Accessed: 07. 15. 2021.]

Lund, E. M. \& Cmar, J. L. (2019). A Systematic Review of Factors Related to Employment Outcomes for Adults with Visual Impairments. Journal of Visual Impairment \& Blindness, 113(6), 493-517. https://doi.org/10.1177/0145482X19885211

McDonnall, M. C. \& Sui, Z. (2019). Employment and unemployment rates of people who are blind or visually impaired: Estimates from multiple sources. Journal of Visual Impairment \& Blindness, 113(6), 481-492. https://doi.org/10.1177/0145482X19887620

Michalko, R. (2010). What's cool about blindness? Disability Studies Quarterly, 30(3-4), 2016. https://doi.org/10.18061/dsq.v30i3/4

Nagle, K. M. (2001). Transition to Employment and Community Life for Youths with Visual Impairments: Current Status and Future Directions. Journal of Visual Impairment and Blindness, 95(12), 725-738. https://doi.org/10.1177/0145482X0109501203

OECD \& The European Commission (2004). Career Guidance: a Handbook For Policy Makers. OECD.

Population Census (2011). https://www.ksh.hu/nepszamlalas/tablak_fogyatekossag [Accessed: 31. 08. 2021.]

Rose, S. F. (2015). Work. In Adams, R., Reiss, B. \& Serlin, D. (eds). Keywords for Disability Studies (pp. 187-190). New York: New York University Press.

Rosenthal, G. (1993). Reconstruction of life stories. In Josselson, R. \& Lieblich, A. (eds). The narrative study of lives (pp. 51-91). SAGE Publications.

Sears, S. H., Jones, A. \& Strauser, D. R. (2014). Career Counseling with People with Disabilities. In Strauser, D. (ed.). Career Development, Employment and Disability in Rehabilitation: From Theory to Practice (pp. 277-295). Springer.

Shakespeare, T. (2006). The Social Model of Disability. In J. L. Davis (ed.). The Disability Studies Reader. Second Edition (pp. 197-205). New York, NY: Routledge.

Shakespeare, T. (2013). Disability Rights and Wrongs Revisited. Routledge. https://doi. org/10.4324/9781315887456

Svastics C., Csillag S. \& Győri Z. (2020). Entrepreneurs with Disabilities in Hungary. a New Solution for Work Inclusion? Hungarian Journal Of Disability Studies \& Special Education, Special Issue, 152-165. https://doi.org/10.31287/FT.en.2020.2.12

Szymanski, E.M. \& Jeff Vancollins, J. (2003). Career Development of People with Disabilities: Some New and Not-So-New Challenges. Australian Journal of Career Development, 12(1), 9-16. https://doi.org/10.1177/103841620301200103

Titchkosky, T. (2002). Cultural Maps: Which way to Disability? In M. Corker \& T. Shakespeare (eds). Disability/Postmodernity. Embodying disability theory (pp. 101-111). Continuum.

Török, R. (2020). The Founding of a Service Centre. The Most Significant Results of the Content and Methodological Developments Conducted by the Kilátó Piarist Career Guidance and Labour Market Development Centre. Journal of Disability Studies \& Special Education, Special Issue, 88-103. https://doi.org/10.31287/FT.en.2020.2.8

UN Disability and Employment Factsheet. https://www.un.org/development/desa/disabilities/ resources/factsheet-on-persons-with-disabilities/disability-and-employment.html [Accessed: 17. 07. 2021.]

Vision Australia. https://www.visionaustralia.org/community/news/2019-08-23/survey-showsblind-people-significantly-underemployed-around-world [Accessed: 17. 07. 2021.]

Warr, P. (2011): Work, Happiness, and Unhappiness. Taylor and Francis. https://doi. org/10.4324/9780203936856

Watts, A. G. (2013). Career Guidance and Orientation. In UNESCO. Revisiting global trends in TVET: Reflection on theory and practice. UNESCO.

WHO (2021). Blindness and vision impairment. https://www.who.int/news-room/fact-sheets/ detail/blindness-and-visual-impairment [Accessed: 07. 09. 2021.]

World Report on Disability. https://ecommons.cornell.edu/handle/1813/76805 [Accessed: 17. 07. 2021.] 